University of Nebraska - Lincoln

DigitalCommons@University of Nebraska - Lincoln

Faculty Publications from the Harold W. Manter Laboratory of Parasitology

2001

\title{
A New Lungworm in Muskoxen: an Exploration in Arctic Parasitology
}

Susan J. Kutz

University of Saskatchewan, susan.kutz@usak.ca

Eric P. Hoberg

USDA-ARS, eric.hoberg@ars.usda.gov

Lydden Polley

University of Saskatchewan, lydden.polley@usask.ca

Follow this and additional works at: https://digitalcommons.unl.edu/parasitologyfacpubs

Part of the Parasitology Commons

Kutz, Susan J.; Hoberg, Eric P.; and Polley, Lydden, "A New Lungworm in Muskoxen: an Exploration in Arctic Parasitology" (2001). Faculty Publications from the Harold W. Manter Laboratory of Parasitology. 733. https://digitalcommons.unl.edu/parasitologyfacpubs/733

This Article is brought to you for free and open access by the Parasitology, Harold W. Manter Laboratory of at DigitalCommons@University of Nebraska - Lincoln. It has been accepted for inclusion in Faculty Publications from the Harold W. Manter Laboratory of Parasitology by an authorized administrator of DigitalCommons@University of Nebraska - Lincoln. 


\title{
A new lungworm in muskoxen: an exploration in Arctic parasitology
}

\section{Susan J. Kutz, Eric P. Hoberg and Lydden Polley}

\begin{abstract}
Ruminants are vital elements of the Holarctic ecosystem. Little is known, however, of the structure or biology of their parasite fauna, particularly in North America. Global warming, coupled with increasing human activity in the Arctic, requires enhanced international interdisciplinary efforts to better understand the many factors, including parasites, that influence the population health of caribou, reindeer, muskoxen and wild sheep. The discovery of an unusual new genus of protostrongylid lung nematode in muskoxen from the central Canadian Arctic is described, and the intricacies of the parasite's relationship with its muskoxen definitive hosts, its gastropod intermediate hosts and the arctic environment are discussed.
\end{abstract}

Susan J. Kutz* Lydden Polley Dept of Veterinary Microbiology, Western College of Veterinary Medicine, 52 Campus Drive, University of Saskatchewan, Saskatoon, Saskatchewan, Canada S7N 5B4.

*e-mail: susan.kutz @usak.ca

\section{Eric P. Hoberg}

US Dept of Agriculture Agricultural Research Service, Biosystematics Unit of the Parasite Biology, Epidemiology and Systematics Laboratory, BARC East No. 1180, 10300 Baltimore Avenue, Beltsville, MD 20705, USA.
Fig. 1. Map of northern Canada showing historical and contemporary distributions of muskoxen in the Northwest Territories (NT) and Nunavut (NU) and the location of the field study. Hatched areas indicate the muskox range in 1930 (Arctic islands) and in 1940 (mainland). Solid grey areas indicate the current muskox range 20 .
In the Canadian Arctic, ruminants, particularly caribou (Rangifer tarandus) and muskoxen (Ovibos moschatus), are keystones for the maintenance and vitality of remote communities. Across the almost four million square kilometers of the Yukon (YT), Northwest Territories (NT) and Nunavut (NU), many of the 100000 residents depend on these species, and other wildlife, as sources of food, through subsistence hunting, and as foci of economic activity, through commercial and sport hunting, and tourism. In this climatically extreme and isolated region, boreal coniferous forests in the south give way to the windswept tundra of the high Arctic, with mountainous areas in YT, western NT and on Baffin and Ellesmere islands in eastern NU (Fig. 1). At these northern latitudes, solar energy is an important limiting factor for ecosystem structure and biodiversity, where biotic growth and production are limited to short but intense summers.

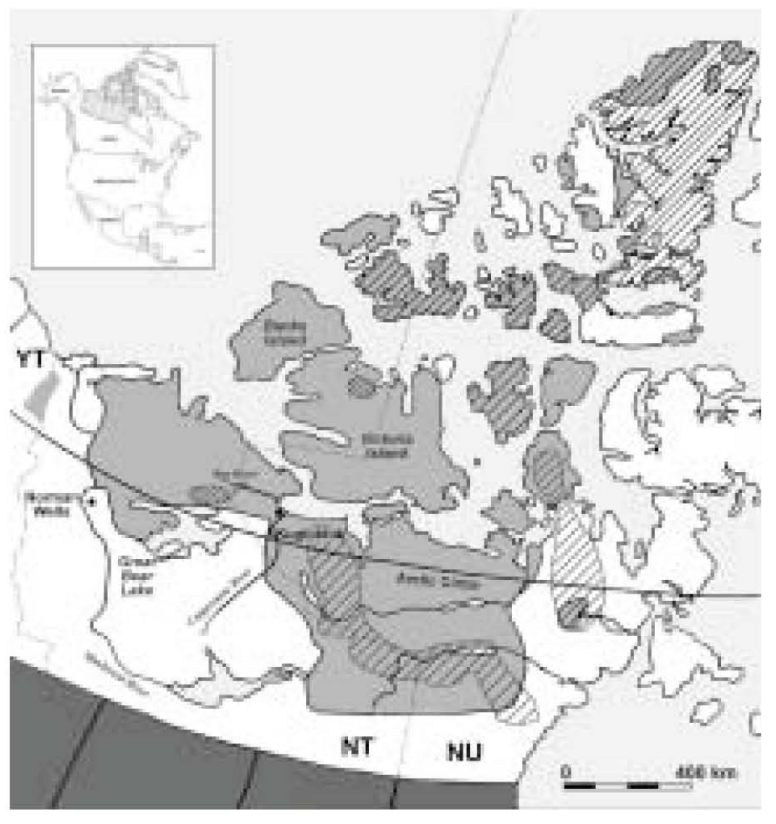

Parasite diversity in the Arctic

Although we understand much about the biology of ruminants at high latitudes, our knowledge of their parasite fauna is incomplete, even for fundamental issues such as parasite biodiversity. Systematics research is essential for documentation of biodiversity, accurate description and identification of parasites, and for defining the distribution and historical relationships of host-parasite assemblages ${ }^{1}$. This accurate documentation is vital for understanding disease processes in ruminants, the role of parasites as potential regulators of host populations, and the complex biotic and abiotic parameters that can influence the geographic distribution, epidemiology and significance of the parasites ${ }^{2,3}$.

Hidden diversity in the Arctic has been illustrated dramatically by a series of recent discoveries of a new genus and two new species of nematodes ${ }^{4-6}$, and of new host and geographic records ${ }^{7}$. Recognition that our knowledge of the arctic parasite fauna is inadequate comes at an important time. Northern ecosystems are under increasing pressure from resource development, and the effects of global warming are already evident in the arctic environment ${ }^{8}$. Our limited understanding of host-parasite relationships in the Arctic hinders development of predictions about the possible effects of climate change and human activity on the health of wildlife populations and on the emergence of parasite-associated disease.

The discovery of a new lung nematode in muskoxen During the late 1980s, adult muskoxen west of Kugluktuk, NU, a coastal community in the central Canadian Arctic, were found with massive infections of an apparently unknown protostrongylid nematode confined to prominent and well-defined cysts (up to $40 \mathrm{~mm}$ in diameter) in the lung parenchyma ${ }^{4,5}$ (Fig. 2a). Preliminary attempts to recover intact parasites from frozen or fixed tissue were unsuccessful because the adult nematodes were coiled tightly in a robust matrix of eggs, dorsal-spined first-stage larvae, inflammatory cells and exudate. In April 1994, however, adult nematodes, substantially larger than any of the known protostrongylids, were dissected over a period of several days from pulmonary cysts in two freshly killed muskoxen. The entire adult males (up to $171 \mathrm{~mm}$ in length) and an adult female (468 mm), along with numerous anterior and posterior fragments, provided the basis for a new genus and species, Umingmakstrongylus pallikuukensis 
Fig. 2. Cross-section of lung from muskox infected with Umingmakstrongylus pallikuukensis showing cysts (thick arrows) containing adult nematodes (thin arrow) (a). Transverse computed tomography image of lung from muskox infected with $U$. pallikuukensis showing cysts (arrows) (b). Scale bars $=1 \mathrm{~cm} \mathrm{(a);} 3 \mathrm{~cm}(\mathrm{~b})$.
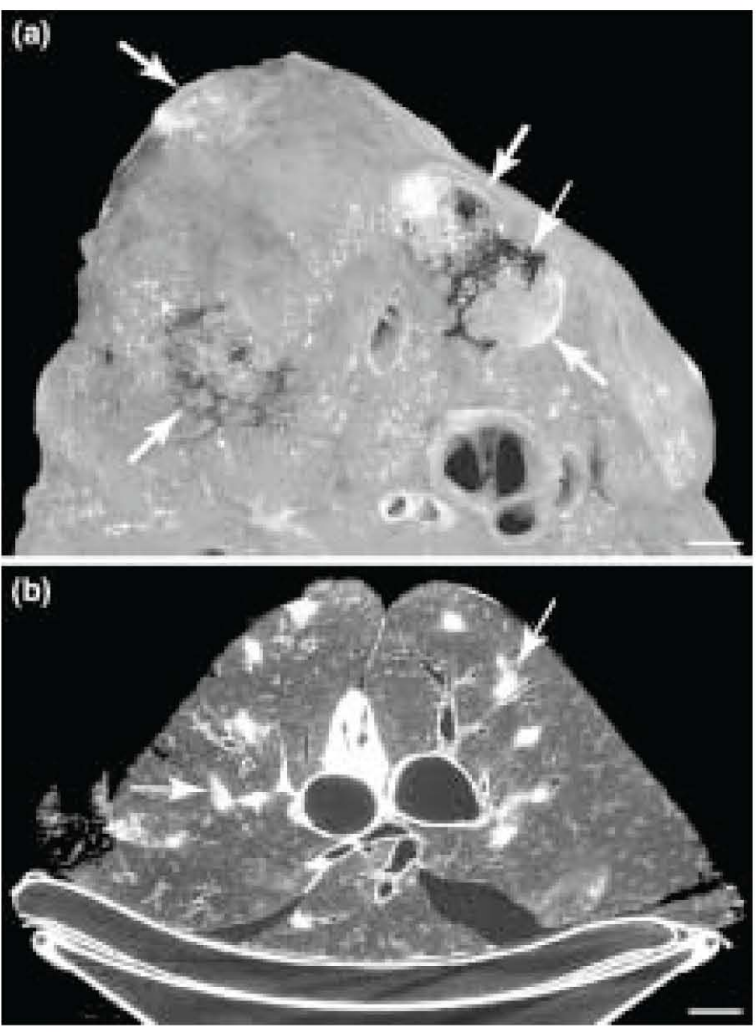

(Protostrongylidae: Muelleriinae $)^{5}$. This name reflects the host, its geographic location and the local culture: Umingmak is Inuinnaqtun (the local dialect of the Inuit) for muskoxen; 'strongylus' for the strongylate nematodes; pallik is Inuinnaqtun for the region surrounding the watershed of the Rae and Richardson valleys, west of Kugluktuk; and kuuk signifies river.

In 1994, a broad-based research program was initiated, with direct input from local residents and wildlife biologists. A key rationale for investigating this new parasite was a decline in the muskox population west of Kugluktuk, between 1988 and 1994, from approximately 1800 to near 900 . In addition, observations by resident hunters that muskoxen heavily infected with $U$. pallikuukensis might exhibit reduced exercise tolerance, lag behind the group, have difficulty breathing and, in some cases, bleed from the nose ${ }^{5}$, raised questions about the role of this lungworm in the health of the muskox population.

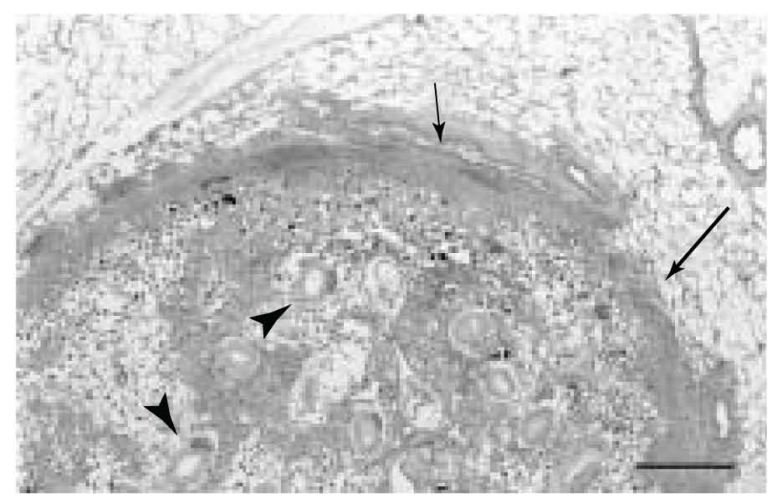

Field and laboratory studies since 1994 have assembled considerable information on several aspects of $U$. pallikuukensis, including development and pathology in muskoxen, development in the intermediate hosts, epidemiology in the Arctic, and host and geographic distributions ${ }^{9-12}$. These studies serve as a model for: (1) understanding a newly recognized parasite in a remote and severe environment; (2) predicting and assessing biotic impacts of climate change in high-latitude ecosystems; and (3) interdisciplinary, team- and problem-based research in the Arctic.

\section{Umingmakstrongylus pallikuukensis in the muskox definitive hosts}

Umingmakstrongylus pallikuukensis is well established in the infected muskox population; prevalence approaches $100 \%$, and a maximum of 258 cysts were observed in one old bull ${ }^{4}$. Field data suggest that infection intensities increase as the host ages, with the highest infection levels in old bulls ${ }^{4}$. The prepatent period of $U$. pallikuukensis (approximately 90 days in experimental infections ${ }^{9}$ ) is long compared to those of other protostrongylid lungworms (e.g. Cystocaulus and Muellerius) ${ }^{13}$, and the patent period can extend for at least two years, with larval counts of 2000 per gram of feces, 26 months post-infection ${ }^{9}$.

In the lungs of muskoxen, cysts containing U. pallikuukensis are visible radiographically by six months post-infection, and computed tomography shows that they are associated spatially with the primary airways and blood vessels (Fig. 2b) ${ }^{10}$. Major histopathological changes are restricted to the cysts that communicate with airways, allowing eggs, larvae and other material to leave the lungs (Fig. 3) $)^{5,9}$

The role of $U$. pallikuukensis in the health of muskoxen, at individual and population levels, remains unknown. The symptoms shown by some animals, notably the impaired exercise tolerance, suggest that heavy infections might make them more susceptible to predators, especially grizzly bears ${ }^{\dagger}$. It is not known whether the presence of multiple lung cysts, together with eggs, larvae, and perhaps increased amounts of fluid in the airways, predisposes affected animals to other respiratory infectious agents, or whether the parasite has other deleterious effects on muskoxen.

\section{Umingmakstrongylus pallikuukensis in the gastropod intermediate hosts}

Umingmakstrongylus pallikuukensis, like other protostrongylids, requires gastropod intermediate hosts to develop to infective third-stage larvae (L3) ${ }^{9}$ (Fig. 4). Among ten gastropod species found in the range of the naturally infected muskoxen,

${ }^{\dagger}$ Gunn, A. et al. (1991) Wildlife diseases and parasites in the Kitikmeot region. File Report No. 104. Dept of Renewable Resources, Government of the Northwest Territories, Yellowknife, NT. 
Fig. 4. Life cycle for Umingmakstrongylus pallikuukensis. L1, first-stage larva; L3, third-stage larva.

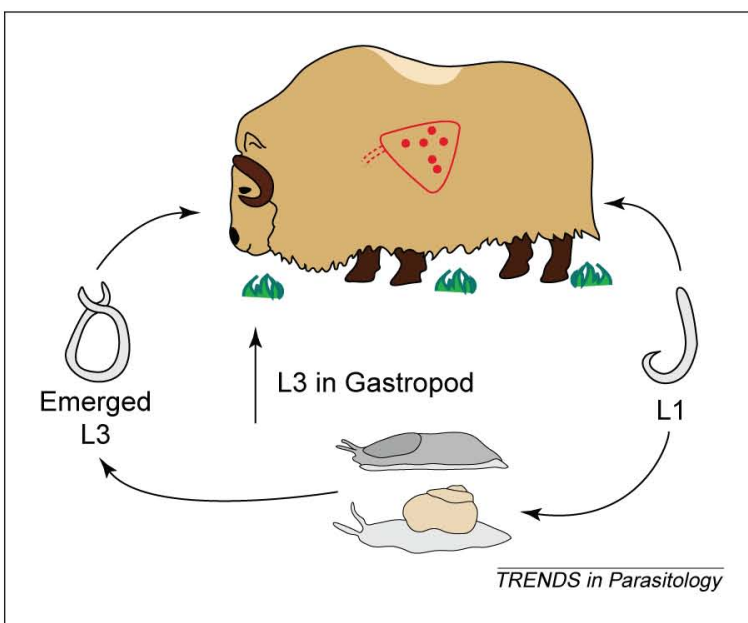

development of first-stage larvae (L1) to L3 occurs under laboratory conditions in the slug Deroceras laeve, in the terrestrial snails Euconulus fulvus, Columella alticola and Catinella sp., and in the freshwater snail Aplexa hypnorum (S.J. Kutz, PhD thesis, University of Saskatchewan, 2000). The relative importance of each of these species for transmission in the Arctic has yet to be determined.

The development of the larval stages of protostrongylids is dependent on temperature. In $D$. laeve, the rate and synchrony of larval development for $U$. pallikuukensis to L3 are correlated positively with temperature. For example, at $20^{\circ} \mathrm{C}$ development to $L 3$ requires 12 days and larvae recovered on that day are all at the $\mathrm{L} 3$ stage; at $11.5^{\circ} \mathrm{C}$, development to $\mathrm{L} 3$ requires almost 50 days, and a proportion of the larvae recovered are first- or second-stage ${ }^{12}$. The calculated threshold temperature (below which larval development is not detected) for $U$. pallikuukensis in D. laeve is $8.5^{\circ} \mathrm{C}$ and the thermal constant (heat required for $\mathrm{L} 1$ development to L3) is 167 degree days ${ }^{12}$.

A unique model, using small tundra enclosures, was developed for quantitative and qualitative examination of $U$. pallikuukensis larval development in D. laeve under ambient field conditions. Experiments near Kugluktuk in 1997 and 1998, the fifth warmest and the warmest years on record respectively (Environment Canada, www1.tor.ec.gc.ca/ccrm/bulletin/archive/ htm), suggest that even in these unusually warm years, $U$. pallikuukensis has a narrow seasonal window for development to infective L3. In slugs infected experimentally in June or early July of 1997 or 1998, L3 were present in 4-8 weeks and, with a constant rate of infection throughout the spring and summer, maximum intensity of L3 in slugs occurred in mid- to late August. Some of these slugs survived on the tundra over winter, and still contained L3 the following spring. In slugs infected towards the end of July or later in 1997, L3 did not develop before winter, but L1 and L2 survived over winter in slugs on the tundra and completed development the following spring and summer. Larvae overwintering in slugs might be an important source of L3 in late spring and early summer, and might be available to muskoxen earlier than the cohort developing in gastropods infected during that spring. A simple mathematical model for larval development was derived from the calculated threshold temperature, the thermal constant and soil surface temperatures observed within the tundra enclosures. Predictions from this model correspond with development rates observed in the field (S.J. Kutz, op. cit.).

\section{Larval emergence}

Muskoxen might become infected with

$U$. pallikuukensis following ingestion of gastropods containing L3 or by the ingestion of L3 that have emerged spontaneously from infected gastropods ${ }^{9}$. In laboratory experiments with $D$. laeve, $D$. reticulatum and Catinellasp., up to $100 \%$ of the L3 emerged from the live gastropods by 60 days post-infection ${ }^{11}$. In addition, in field experiments, the recovery of live L3 from vegetation ${ }^{11}$, together with the observed decline in L3 intensity in experimentally infected slugs in the enclosures in late summer (S.J. Kutz, op. cit.), suggests that L3 might also emerge under natural conditions, from live or dead slugs, and survive for an undetermined period. These observations on larval emergence by $U$. pallikuukensis are unexpected, and challenge the current understanding of development and transmission dynamics for protostrongylids.

Although L3 emergence has been reported for several protostrongylids, including Cystocaulus ocreatus and Muellerius capillaris of sheep, and Protostrongylus boughtoni of hares, it is considered to be a rare event and probably of limited epidemiological significance $^{14,15}$. Among the related Angiostrongylidae, however, L3 of Angiostrongylus cantonenesis and $A$. costaricensis are known to emerge from their gastropod intermediate hosts, and these emerged larvae are thought to be important for parasite transmission ${ }^{16,17}$.

\section{Epidemiology in the Arctic}

Despite the constraints of the arctic environment, $U$. pallikuukensis seems to thrive in the muskox population west of Kugluktuk. The high prevalence, the high intensity in some animals ${ }^{4}$, the long life span of the adult parasites, together with the extended patent period and high rates of larval shedding ${ }^{9}$, should ensure continuity of parasite populations over time. These features may act as a buffer for the parasite during years when summer conditions are unsuitable for larval survival in the environment or development in intermediate hosts. In addition, although transmission might depend primarily on L3 in slugs in late summer, larvae overwintering in gastropods, and those emerged from gastropods, represent potential sources of infection ${ }^{9,11}$. These various L3 populations could have significantly different spatial and temporal distributions in addition to different survival characteristics on the tundra, all of which might influence transmission dynamics. Epidemiological patterns in these 
seasonally defined environments are likely to be influenced by climate change ${ }^{8}$.

\section{Host and geographic distributions}

Umingmakstrongylus pallikuukensis appears to be host specific. It has not been found in the Bluenose East caribou herd which shares range with the infected muskox population, nor in Dall's sheep from the Mackenzie Mountains, NT (S.J. Kutz, unpublished), and attempts to infect domestic sheep experimentally with this parasite have been unsuccessful ${ }^{9}$. The geographic distribution of $U$. pallikuukensis also seems to be limited. It has been found only in muskoxen in the region extending from Great Bear Lake northward to the Arctic Coastal Plain, and from the Mackenzie River eastward slightly beyond the Coppermine River (Fig. 1). Records are unknown from other areas of the mainland NT and NU, the arctic islands, including Banks and Victoria, from East Greenland, and from populations of muskoxen introduced in Scandinavia or Alaska ${ }^{5}$.

The distribution of parasites represents an interplay of contemporary and historical factors ${ }^{1,5,6}$. The origin and the restricted host and geographic distributions of $U$. pallikuukensis remain enigmatic. Solving this enigma will depend on examination of historical limiting factors, for example glacial-refugial effects, within the context of parasite faunas in all arctic ruminants ${ }^{5,6,18}$, and on more recent events in the Arctic. Phylogenetic studies of protostrongylids in ruminants suggest a hostswitch by a muelleriine nematode from caprine bovids at a minimum during the Pleistocene $e^{5,19}$. Historical and recent changes in distribution and density of muskoxen, gastropod availability, environmental conditions, and other factors affecting maintenance and transmission of U. pallikuukensis might explain its current geographic distribution ${ }^{5}$. For example, extirpations of muskoxen from much of their range on mainland NT and NU, associated with hunting during the nineteenth and early twentieth centuries, resulted in two isolated populations in the 1930s and 1940s (Fig. 1). Since that time, these populations have expanded to inhabit most of the mainland tundra above the treeline, but the distribution of U. pallikuukensis remains restricted (Fig. 1).

\section{Global climate change}

Impacts of global warming are predicted to be most marked in the Arctic ${ }^{8}$. In the Mackenzie River valley of the western NT (Fig. 1), temperatures over the past decade have exceeded normal values consistently: nine years between 1990 and 1999 had annual mean temperatures 0.3 to $3.9^{\circ} \mathrm{C}$ above the 30 -year average; and five of the ten warmest years since 1948 have occurred in the 1990s (Climate Trends and Variations Bulletin for Canada, 2000. Environment Canada, Meteorological Service of Canada, Climate Research Branch: www1.tor.ec.gc.ca/ccrm/bulletin/archive/ $\mathrm{htm})$. This warming could have profound effects on the muskox-Umingmakstrongylus system and other host-parasite assemblages. Alterations in temperature, precipitation or vegetation could modify geographic distribution, density or survival of mammalian or gastropod hosts, in addition to larval development and survival of free-living L1s or emerged L3s. Elevated temperatures could increase larval development rates within the intermediate hosts and extend the seasonally defined windows for development and transmission to earlier in the spring and later in the autumn ${ }^{18}$. These perturbations could lead to amplification of parasite populations, ultimately influencing muskox population health. The field experiments with $U$. pallikuukensis provide a preliminary model system for monitoring, and perhaps predicting, the effects of climate variation on protostrongylid larval development, and on the development of other parasites in northern ecosystems.

\section{A model for interdisciplinary studies}

Research on the biology of $U$. pallikuukensis has demonstrated the significant role for synergistic linkages among parasitology, veterinary medicine, wildlife biology and community-level concern for natural resources ${ }^{1}$. This research program started with the discovery of a new parasite and became the focus of a multifaceted exploration of a host-parasite system in an extreme environment. The work with $U$. pallikuukensis, together with other recent parasitological discoveries, is changing fundamentally our perceptions of the complexity of host-parasite systems in the Arctic ${ }^{5,6}$. It has alerted us to how little is known about parasite biodiversity, biology and epidemiology in the north, and has stimulated the development of broader international collaborations to document and monitor

host-parasite systems in the Holarctic. Finally, it has emphasized the importance of continued exploration of parasites and other infectious agents in the Arctic, where even small changes in climate, human activities or other ecosystem components can significantly influence the vitality of the wildlife resources on which many northerners depend, and that so enrich the landscape and the human spirit. nematodes in Svalbard reindeer (Rangifer tarandus platyrhynchus). Parasitology 120, 297-311

4 Gunn, A. and Wobeser, G. (1993) Protostrongylid lungworm infection in muskoxen, Coppermine, N.W.T, Canada. Rangifer 13, 45-47

5 Hoberg, E.P. et al. (1995) Umingmakstrongylus pallikuukensis gen.nov. et sp.nov. (Nematoda: Protostrongylidae) from muskoxen, Ovibos moschatus, in the central Canadian Arctic, with comments on biology and biogeography. Can. J. Zool. 73, 2266-2282

6 Hoberg, E.P. et al. (1999) Structure, biodiversity and historical biogeography of nematode faunas in holarctic ruminants: morphological and molecular diagnoses for Teladorsagia boreoarcticussp. n. (Nematoda: Ostertagiinae), a dimorphic cryptic species in muskoxen (Ovibos moschatus). J. Parasitol. 85, 910-934

7 Kutz, S.J. et al. New host and geographic records 
for two protostrongylids in Dall's Sheep. J. Wildl. Dis. (in press)

8 Weller, G. and Lange, M., eds (1999) Impacts of global climate change in the Arctic regions. Report from a Workshop on the Impacts of Global Change, 25-26 April 1999, Tromsø, Norway. Published for the International Arctic Science Committee (IASC) by the Center for Global Change and Arctic System Research, University of Alaska Fairbanks, Fairbanks, Alaska

9 Kutz, S.J. et al. (1999) Experimental infections of muskoxen (Ovibos moschatus) and domestic sheep with Umingmakstrongylus pallikuukensis (Nematoda: Protostrongylidae): parasite development, population structure and pathology. Can. J. Zool. 77, 1562-1572

10 Kutz, S.J. et al. (1999) A lung nematode in Canadian arctic muskoxen: standard radiographic and computed tomographic imaging. Vet. Clin. North Am.: Food Anim. Practice 15, 359-377

$11 \mathrm{Kutz}$, S.J. et al. (2000) Emergence of third-stage larvae of Umingmakstrongylus pallikuukensis from three gastropod intermediate host species.
J. Parasitol. 86, 743-749

12 Kutz, S.J. et al. Umingmakstrongylus pallikuukensis (Nematoda: Protostrongylidae) in gastropods: larval morphology, morphometrics, and development rates. J. Parasitol. (in press)

13 Gerichter, C.B. (1951) Studies on lung nematodes of sheep and goats in the Levant. Parasitology 41 , 166-182

14 Boev, S.N. (1975) Protostrongylids. In Fundamentals of Nematology (Vol. 25), Helminthological Laboratory, Academy of Sciences of the USSR, Moscow. (Engl. trans. 1984, US Dept of Agriculture, Washington, DC, and Amerind Publishing Co., New Delhi, India)

15 Kralka, R.A. and Samuel, W.M. (1984) Emergence of larval Protostrongylus boughtoni (Nematoda: Metastrongyloidea) from a snail intermediate host and subsequent infection in the domestic rabbit (Oryctolagus cuniculus). J. Parasitol. $70,457-458$

16 Heyneman, D. and Lim, B-L. (1967) Angiostrongylus cantonensis: proof of direct transmission with its epidemiological significance. Science 158, 1057-1058

17 Ubeleker, J.E. et al. (1980) Emergence of third-stage larvae of Angiostrongylus costaricensis Morera and Cespedes 1971 from Biomphalaria glabrata (Say). J. Parasitol. 66 , 856-857

18 Hoberg, E.P. et al. (2001) Gastrointestinal strongyles in wild ruminants from North America, in Parasitic Diseases of Wild Mammals (Samuel, W.M. et al., eds), pp. 193-227, Iowa State University Press

19 Carreno, R. and Hoberg, E.P. (1999) Evolutionary relationships among the Protostrongylidae (Nematoda: Metastrongyloidea) as inferred from morphological characters, with consideration of parasite-host coevolution. J. Parasitol. 85, 638-648

20 Fournier, B.and Gunn, A. (1998) Muskox numbers and distribution in the Northwest Territories, 1997. File Report No. 121. Department of Resources, Wildlife and Economic Development, Government of the Northwest Territories, Yellowknife, NT, Canada. 